\title{
Suum Cuique Tribuere - A Common Narrative of Federalism and Equality?
}

\author{
Anna Gamper
}

Suum cuique tribuere - to give each his own, ascribed to Ulpian in Justinian's Digest $^{2}$ - is one of the three components of law and justice to which the relevant chapter 'de iustitia et iure' is dedicated. According to the programmatic beginning, justice is the constant and perpetual will of ius suum cuique tribuendi. ${ }^{3}$ The legal precepts are as follows: to live honestly, to injure no one and to give each his own. ${ }^{4}$

The enigma of this ancient formula has enthralled legions of legal scholars over centuries. However, the idea of suum cuique tribuere has an even older origin: it can definitely be traced back to Plato's ${ }^{5}$ and Aristotle's ${ }^{6}$ discourses on equality, and, according to some, to the Seven Sages, ${ }^{7} \mathrm{Hesiod}^{8}$ and even to Babylonian law. ${ }^{9}$ Notwithstanding its exact origins, there is no doubt that the principle it expresses has been recognised as an essential component of law and justice since ages.

In spite of how inspiring the principle has been, not all legal scholars have appreciated it. Within the domain of public legal theory, Hans Kelsen sharply criticised it, calling it a 'completely empty' and 'totally worthless' phrase. ${ }^{10}$

\footnotetext{
$1 \quad$ I am grateful to MMag. Dr. Mathias Eller for his help in editing the footnotes.

$2 \quad$ Dig. 1.1.10.1.

3 Dig. 1.1.10pr.

4 Dig. 1.1.10.1: 'Iuris praecepta sunt haec: honeste vivere, alterum non laedere, suum cuique tribuere.'

5 See the nearly identical sentence ('to have and do one's own would be recognized as justice') in Plato, Politeia, 433e. Two different equalities are identified by Plato, Nomoi, 757 b.

6 Aristotle, Politika, 1302; Aristotle, Ethika Nikomacheia, 1130-1131.

$7 \quad$ Hans Kelsen, Was ist Gerechtigkeit? (Vienna: Deuticke, 1953), 23.

8 Wolfgang Waldstein, "Zu Ulpians Definition der Gerechtigkeit," in FS Werner Flume, eds. Horst H. Jakobs et al. (Köln: Verlag Dr. Otto Schmidt KG, 1978), 218.

$9 \quad$ Waldstein, “Definition," 218.

10 Kelsen, Gerechtigkeit, 23-24; Hans Kelsen, Die Illusion der Gerechtigkeit (Vienna: Manz Verlag, 1985), 221. Critically on Kelsen's assessment of suum cuique, Wolfgang Waldstein, "Ist das 'Suum cuique' eine Leerformel?," in FS Alfred Verdross, eds. Herbert Miehsler et al.
} 
From the perspective of legal positivism, Kelsen was right in arguing that there was no absolute or general notion of suum, so that the question of what the suum is depends on each concrete legal system. ${ }^{11} \mathrm{He}$ was, however, incorrect in neglecting the cuique: the substance of the phrase does not exhaust itself in the suum, but it also postulates that each and every one, and not just some, should be treated according to this rule. Clearly, it depends on the respective suum - and the respective legal system that decides on the suum - whether this amounts to equal or unequal treatment, but at least the rule as such is applicable to everyone and not only to some. Moreover, the rule is also based on an individualist approach. It presumes differences between individuals, since there would otherwise be no need to speak of suum, and thus suggests proportionality. Thus, even though the rule does not define the exact meaning of suum, it nevertheless provides two basic hypotheses that are neither empty nor worthless: (1) If a legal system defines the suum by certain criteria, all those that meet these criteria must be treated equally among themselves. (2) There is a necessity for law to consider individual positions and to reflect these through different provisions: the suum - which is neither everything nor anything - suggests some proportionality between the individual and their legal treatment. Putting suum cuique tribuere into the context of the two preceding statements, namely honeste vivere and neminem laedere, there are, moreover, two substantive indicators of justice that also suggest a truth-oriented, rational and proportionate approach. ${ }^{12}$

Little attention seems to have been paid to the subtle distinction between suum cuique tribuere and the preceding preamble according to which iustitia est constans et perpetua voluntas ius suum cuique tribuendi. It is thus not only 'to give each his own', but also 'to give each his law'. Putting both sentences in context, justice is a constant and perpetual will to give each their law, and the law itself needs to give each their own. This does not imply that law will never change - according to factual changes, it would possibly need to - but that there can be no justice without a continuous consideration of an individual's position in law.

(Berlin: Duncker \& Humblot, 1980), 285-320 (with further references); Anna Gamper, "'Arithmetische' und 'geometrische' Gleichheit im Bundesstaat," in Vom Verfassungsstaat am Scheideweg - FS Peter Pernthaler, eds. Karl Weber and Norbert Wimmer (Vienna, New York: Springer, 2005), 145-146.

11 Kelsen, Gerechtigkeit, 23-24; Hans Kelsen, Reine Rechtslehre (Vienna: Verlag Österreich, 2000), 366-367.

12 A modern transplant of the neminem laedere-principle into the federal context is the principle of mutual consideration; see, on its relation to the equality principle, Peter Bußjäger, "Bundesstaat und Gleichheitsgrundsatz," Juristische Blätter 129, no. 5 (2007): 296-297. 
This chapter will examine the suum cuique-principle in the context of federalism. At first glance, this seems to be a rather unfamiliar environment for the application of this rule. Surely, Ulpian did not elaborate his rule with federalism in view. A close reading, however, reveals that the rule is very closely related to what Plato and Aristotle called 'arithmetic' and 'geometric' justice. ${ }^{13}$ Later, both terms were used to describe what is more commonly referred to as symmetric or asymmetric, formal or substantive, absolute or relative equality. ${ }^{14}$ This chapter seeks to argue that federalism and equality cannot be simply conceived as opposing principles - the one seeking to ensure diversity management, the other to establish homogeneity ${ }^{15}$ We can neither regard absolute equality as the one and only type of equality, nor can we contend that relative equality means everything or anything. Relative equality therefore requires the yardstick of proportionality and reasonable justification. Whatever the suum is, and even if it differs from the suum of others, it must be proportional and reasonably justified by facts. If we apply these requirements in the context of federal states, i.e. use the suum cuique-principle as a test, asymmetries would need to be justified by factual differences, such as, inter alia, territorial size or number of inhabitants. But do these factors offer a sufficient justification in all cases? And how can federalism legitimise the unequal treatment of persons living in different regions? Is there a 'true' federalism, and is this the symmetric federalism firstly conceived by the Federalist Papers?

\section{Federalism and Formal Equality}

Formal equality means absolute equality: equality that entails a strictly identical legal treatment. It is symmetric and, in terms of the ancient world, arithmetic, since it neither considers nor establishes differences. ${ }^{16}$ Liberal constitutional theory regards formal equality as one side of a Janus-faced principle that, on the other side, allows for different legal treatment if this is proportional and reasonably justified by factual differences. ${ }^{17}$

13 Plato, Gorgias, 508a; Aristotle, Politika, 1302; Aristotle, Ethika Nikomacheia, 1131. See also Kelsen, Illusion, 220-221.

14 Peter Pernthaler, Der differenzierte Bundesstaat (Vienna: Braumüller, 1992), 4; Gamper, "Gleichheit," 144, both with further references.

15 Peter Bußjäger, Homogenität und Differenz (Vienna: Braumüller, 2006), 48.

16 Gamper, "Gleichheit," 146.

17 Susanne Baer, "Equality," in The Oxford Handbook of Comparative Constitutional Law, eds. Michel Rosenfeld and András Sajo (Oxford: Oxford University Press, 2012), 986 and 994996; Brun-Otto Bryde and Michael A. Stein, "General Provisions Dealing with Equality," in 
Federalism is a principle that combines diversity and unity. ${ }^{18}$ In constitutional terms, it provides for at least two tiers that are vested with legislative and executive powers, including constitution-making power, for representation of the component units at federal level, for fiscal autonomy and/or equalisation as well as instruments and measures that ensure cooperation and coordination between the tiers. ${ }^{19}$ At first glance, absolute equality is indeed not compatible with federalism, since it would be constitutionally impossible to treat the federal level identically with the component units. The allocation of powers necessarily implies differences between the powers of the federation and those of the component units. In this sense, federalism and equality are indeed opposing principles: firstly, it is inherent in federalism to distinguish between the federal level and the component units. Secondly, the very fact that there is more than one component unit entails that the powers allocated at component level may be used differently or only by some, while others abstain. ${ }^{20}$ The legal diversity stemming from these different legal regimes implies that, within certain fields, federal citizens may be treated differently from region to region. As the Austrian Constitutional Court put it: 'It lies in the nature of a federal state to regulate similar state tasks differently within the framework of those powers that are constitutionally attributed to the Länder.'21 Accordingly, 'the principle of federalism excludes that the equality principle is applied to the relation between the laws enacted by different legislatures'. ${ }^{22}$ This is, however, only applicable with respect to the interrelationship between the federal and the component tiers or the component tiers among themselves. The equality principle remains, of course, applicable to the law enacted at each level, ${ }^{23}$ and individuals may enjoy equality rights accordingly.

Absolute equality is, however, not incompatible with federalism inasmuch as it demands structural parity between the federal and the component levels

Routledge Handbook of Constitutional Law, eds. Mark Tushnet, Thomas Fleiner and Cheryl Saunders (London, New York: Routledge, 2013), 288.

18 Ronald L. Watts, Comparing Federal Systems (Montreal, Kingston: McGill-Queen's University Press, 2008), 8; Gamper, "Gleichheit," 143.

19 Watts, Systems, 9; Anna Gamper, Staat und Verfassung (Vienna: Facultas, 2014), 86-108; with more detail, John Kincaid, "Comparative Observations," in A Global Dialogue on Federalism, Vol. 1: Constitutional Origins, Structure, and Change in Federal Countries, eds. John Kincaid and Alan Tarr (Montreal: McGill-Queen's University Press, 2005), 419.

$20 \quad$ Gamper, "Gleichheit," 151.

21 Cf., e.g., VfSlg 19.964/2015, 14.783/1997, 14.644/1996 and 12.949/1991.

22 Cf., e.g., VfSlg 19.964/2015, 19.202/2010, 18.338/2008, 16.843/2003, 14.846/1997 and 13.235/ 1992. See also Bußjäger, "Bundesstaat," 292-294.

23 See, with more detail, Bußjäger, "Bundesstaat," 292-293. 
and among the latter, ${ }^{24}$ even though this parity may be limited (e.g., supremacy of federal law or, at least, of the federal constitution over component law).

Moreover, absolute equality is compatible with federalism inasmuch as the position of the component units vis-à-vis other units are concerned. While the component units will usually exercise their powers differently, federalism does not necessarily require that their respective status or powers as such need to be different. Absolute equality between the component units seems to be suggested by the US American prototype of a federal system: the same powers for every component unit and their equal representation in the Senate. Over the last decades, however, scholars of federalism have increasingly debated whether symmetry between states was essential to federalism. ${ }^{25}$ While they have not, as yet, challenged symmetrical federalism as such, they nevertheless challenge the idea that symmetrical federalism is the only 'true' federalism. Instead, they argue that a majority of modern federal systems (that could be classified as such in accordance with certain substantive criteria) are, to some extent, asymmetric and that the US model as a historical prototype of both coming-together and symmetrical federalism - should not be absolutised. ${ }^{26}$ In Orwellian terms, there remains the fear that 'all states are equal, but some states are more equal than others'. Perhaps this fear is also a reason why asymmetric federalism has traditionally been more in need of justification than symmetric federalism and why asymmetry-friendly theory focuses

24 Bußjäger, "Bundesstaat," 29o; Peter Pernthaler, "Differenzierter Föderalismus," in Auf dem Weg zu asymmetrischem Föderalismus?, eds. Francesco Palermo et al. (Bozen: Nomos, 2007), 24 .

25 See, e.g., Charles D. Tarlton, "Symmetry and Asymmetry as Elements of Federalism: A Theoretical Speculation," The Journal of Politics 27, no. 4(1965):861-874; Francesco Palermo, Carolin Zwilling and Karl Kössler, eds. Asymmetries in Constitutional Law (Bozen: Eu RAC, 2009); Francesco Palermo et al., eds., Auf dem Weg zu asymmetrischem Föderalismus? (Bozen: Nomos, 2007); Robert Agranoff, ed., Accommodating Diversity: Asymmetry in Federal States (Baden-Baden: Nomos, 1999); Watts, Systems, 125-130; Michael Burgess, Comparative Federalism: Theory and Practice (London: Routledge, 2006), 209-225; Lidija R. Basta Fleiner and Jean-François Gaudreault-DesBiens, "Federalism and Autonomy," in Routledge Handbook of Constitutional Law, eds. Mark Tushnet, Thomas Fleiner and Cheryl Saunders (London, New York: Routledge, 2013), 151-152.

26 Cf. e.g. Francesco Palermo, "Asymmetries in Constitutional Law - An Introduction," in Asymmetries in Constitutional Law, eds. Francesco Palermo, Carolin Zwilling and Karl Kössler (Bozen: Eurac, 20o9), 12-13; Francesco Palermo, "Asymmetrie als Ordnungsmodell des modernen Föderalismus, Eine vergleichende Analyse," in Auf dem Weg zu asymmetrischem Föderalismus?, eds. Francesco Palermo et al. (Bozen: Nomos, 2007), 10-11; Gamper, "Gleichheit," 157-158. 
on legitimising asymmetric federalism rather than symmetric federalism. ${ }^{27}$ Accordingly, de iure asymmetries tend to be explained by the existence of $d e$ facto asymmetries, while symmetries are commonly accepted despite de facto asymmetries, even though the latter are a reality in all federal systems to a greater or lesser extent. ${ }^{28}$

\section{$3 \quad$ Federalism and Substantive Equality}

\subsection{Which Kind of Asymmetry?}

Substantive equality reflects factual inequality: it legitimises or even requires legal differentiation (including positive discrimination), but this needs to be based on a proportional and reasonable rationale. ${ }^{29}$

In various contexts of federalism, substantive equality comes prominently into play. The first context is the difference between the federal tier on the one side and the component units on the other. ${ }^{30}$ For obvious reasons, federal constitutions do not treat these levels equally. Constitutional differences between the federal and component levels emerge from the allocation of powers, but they may also be found with regard to institutions, democracy or republicanism. ${ }^{31}$ The crucial argument is that each level should be given 'its own', corresponding to factual circumstances. In fact, the principle of subsidiarity, according to which a lower tier should be responsible for all tasks that are in the particular interest of this tier and can be efficiently managed by it, is but the suum cuique-test ${ }^{32}$ transplanted into a multi-level context. ${ }^{33}$ It is precisely because there are factual differences between tiers, because their requirements, conditions and means are different, that it is necessary to take

27 Palermo rightly criticises the longstanding view of symmetrical federalism as the 'rule' and asymmetrical federalism as the 'exception'; Palermo, "Asymmetrie als Ordnungsmodell," 10.

28 Palermo, "Asymmetries in Constitutional Law," 11; Palermo, "Asymmetrie als Ordnungsmodell," 10.

29 Gamper, "Gleichheit," 146-166.

30 Gamper, "Gleichheit," 143 .

31 Federal constitutions may allow for different parliamentary and governmental systems, different forms of representative or direct democracy or even provide crowned heads of state vis-à-vis republican counterparts at regional level (see e.g. Belgium, Malaysia, Canada, Australia; vice versa the United Arab Emirates).

32 Especially, as suggested by Ulpian's variant 'ius suum cuique tribuendi' (Dig. 1.1.1opr.), to give each his or her own law, which could be understood as an allocation of law-making powers at each level.

See also Bußjäger, Homogenität, 48. 
them into account and to give each level its due. Accordingly, there is not just one level that is best suited to manage everything, but a need for the law to recognise and adequately treat different levels. Both subsidiarity and the suum cuique-test do not demand differentiation merely for ideological reasons, but rather consider the characteristics and specificities of each level; they presuppose reasonableness and proportionality.

The second context concerns asymmetries in the relationship between the component units themselves. These asymmetries may be, as Ronald L. Watts called them, 'political asymmetries' 34 or de facto asymmetries, but they may also be asymmetries entrenched by law (first and foremost, the federal constitution, hence Watts' category of 'constitutional asymmetries'35). ${ }^{36}$ Three main 'constitutional asymmetries' shall be examined here: different systems of power allocation, asymmetric representation in federal second chambers, and financial equalisation. These are sometimes accompanied by other asymmetries, e.g. whether the component units are classified under different categories with varying designations and position ${ }^{37}$ or whether the federal constitution provides for differences in their institutional architecture. ${ }^{38}$

\subsection{Asymmetries in the Allocation of Powers}

Classical federal constitutions usually allocate powers coherently: one part of the constitution is dedicated to the entrenchment of the allocation of powers. Incoherent or 'piecemeal' allocation occurs only in exceptional cases, e.g. if

34 Watts, Systems, 125-127; Ronald L. Watts, "Federalism, Federal Political Systems, and Federations," Annual Review of Political Science 1 (1998): 123. See also the overview by Peter Bußjäger, Föderale Systeme (Vienna: Jan Sramek, 2016), 63-73.

Watts, Systems, 127-130; Watts, "Federalism," 123. Sometimes, these matters are regulated not (only) by federal constitutional law (see e.g. with examples Anna Gamper, "Föderale Kompetenzverteilung in Europa: Vergleich und Analyse aus verfassungsrechtlicher Sicht," in Föderale Kompetenzverteilung in Europa, eds. Anna Gamper et al. (BadenBaden: Nomos, 2016), 764-765), so that de iure asymmetry is the more comprehensive term. The importance of differentiating in terms of law - and not just facts - is already suggested by Ulpian's variant 'ius suum cuique tribuendi' (Dig. 1.1.1opr.).

36 On the terminology, see also Louise Tillin, "United Diversity? Asymmetry in Indian Federalism," Publius 37, no. 1 (2006): 48-52; Wilfried Swenden, "Asymmetric Federalism and Coalition-Making in Belgium," Publius 32, no. 3 (2002): 67-68; Klaus von Beyme, "Asymmetric Federalism between Globalization and Regionalization," Journal of European Public Policy 12, no. 3 (2005): 437-443; Michael Burgess, "The Paradox of Diversity Asymmetrical Federalism in Comparative Perspective," in Asymmetries in Constitutional Law, eds. Francesco Palermo, Carolin Zwilling and Karl Kössler (Bozen: Eurac, 2009), 24-25.

37 Watts, Systems, $74^{-76}$ and 127.

38 See, with examples, Watts, Systems, 129-130. 
specific powers, such as constituent constitutional autonomy, are allocated. A much more excessive use of 'piecemeal' allocation has been made in the Austrian context: even though the main body of the distribution scheme is accommodated in a distinct part of the Federal Constitutional Act, other parts of this Act include many more of these rules and, moreover, there are sundry other allocation provisions outside this Act that also have the rank of federal constitutional law. ${ }^{39}$ But although this allocation is fragmented, it is not asymmetric in the sense that the component Länder would receive different kinds of powers. Still, fragmented allocations of powers often indicate asymmetries. ${ }^{40}$ This is particularly so in the case of asymmetric quasi-federal states ${ }^{41}$ such as Italy and Spain: in the Italian case, the competences of the five special regions are entrenched in individual constitutional laws, while the fifteen ordinary regions receive their powers from Art. 117 and 118 of the Italian Constitution. In contrast, the Spanish Constitution itself entrenches only a rudimentary allocation of powers that further delegates the task to the autonomy statutes, which are organic laws, and moreover allows for an individual and progressive increase of powers. A similar situation applies in the UK, which is, if not a quasi-federal system, a very much decentralised state: the Scotland Act 1998, Government of Wales Act 2006 and Northern Ireland Act 1998 contain very different allocations of powers. ${ }^{42}$ In full-fledged federal systems, asymmetries between the component units are less frequent, ${ }^{43}$ but Belgium, in which different powers are given to the linguistic communities on the one hand, and to the regions on the other, constitutes an important exception as well as Canada with regard to Quebec or India with regard to Jammu and Kashmir. ${ }^{44}$ An even more complex example is Russia ${ }^{45}$ with six different types of component units

39 Peter Bußjäger, "Die bundesstaatliche Kompetenzverteilung in Österreich," in Föderale Kompetenzverteilung in Europa, eds. Anna Gamper et al. (Baden-Baden: Nomos, 2016), $527-567$.

40 Gamper, "Kompetenzverteilung," 766.

41 See Michael Keating, "Asymmetrical Government: Multinational States in an Integrating Europe," Publius 29, no. 1 (1999): 77-82.

42 See e.g. Peter Leyland, "The Multifaceted Constitutional Dynamics of U.K. Devolution," International Journal of Constitutional Law 9, no. 1 (2011): 251-273.

43 Ronald L. Watts, "Comparative Conclusions," in A Global Dialogue on Federalism, Vol. 2: Distribution of Powers and Responsibilities in Federal Countries, eds. Akhtar Majeed, Ronald L. Watts and Douglas M. Brown (Montreal: McGill-Queen's University Press, 20o6), 336; Gamper, “Kompetenzverteilung," 766.

44 Art. 370 of the Indian Constitution; see, however, the more cautious approach by Tillin, "Diversity," 52-55.

45 See Giovanni Poggeschi, "Federalism in Russia: Ethnic and Asymmetrical," in Asymmetries in Constitutional Law, eds. Francesco Palermo, Carolin Zwilling and Karl Kössler (Bozen: EURAC, 2009), 97-116. 
or Bosnia and Herzegovina whose entities have different substructures. The most striking asymmetries are to be found in centralised unitary states in which just one particular region - often islands - enjoys a quasi-federal status and is allocated powers accordingly. ${ }^{46}$

There are more subtle ways, however, to create asymmetric allocation regimes than just different laws with different lists of enumerated subject matters. Many federal constitutions allow for asymmetries in tighter compartments, such as single subject-matters, with ensuing discrepancies between the powers of the component units vis-à-vis the federal level: ${ }^{47}$ one example is the possibility for federal laws to be enacted vis-à-vis certain component units, while others remain free to enact their own rules, ${ }^{48}$ or for component units to assume powers in accordance with flexible opt in- and opt out-rules. ${ }^{49}$ This is usually done because of certain needs and expediencies that arise in one unit, but not in another. Such a 'particular legislation on need' could also, according to some federal constitutions, be used by individual component units when they wish to deviate from uniform federal laws. In these cases, the federal constitution does not explicitly or directly privilege some component units against others, but asymmetric options may occur whenever and wherever 'needs' arise. ${ }^{50}$

Full-fledged, coming-together federal states tend to allocate powers symmetrically, ${ }^{51}$ whereas the opposite seems to be true for holding-together and quasi-federal states. ${ }^{52}$ Most of these states were originally designed as unitary states. Their transformation into federal or quasi-federal systems was based on a 'piecemeal' process in which some regions - with strong historical, political, cultural, geographic or ethnic identities - pioneered. Even where other regions have profited from decentralisation at later stages, one can still detect individual or even privileged constitutional positions of pioneer regions. In

46 See also Watts, "Federalism," 123; Gamper, "Kompetenzverteilung," 767.

47 Watts, Systems, 127-128.

48 Cf. e.g. Art. $25^{2}$ of the Indian Constitution or Sec 95 of the Canadian Constitution Act 1867. A similar situation arises when a federal law regulates the same matter, but with different rules applicable in different regions (see e.g. recently the Austrian Constitutional Court's decision VfSlg 20.179/2017, in which the Court held a federal law that had enacted different rules for the respective Austrian Länder to be reasonably justified).

Watts, Systems, 128-129; Peter Pernthaler, "Asymmetrischer Föderalismus als systemübergreifender Ordnungsrahmen der Regionalautonomie," in Die Verfassung der Südtiroler Autonomie, eds. Joseph Marko et al. (Bozen: Nomos, 2005), 107; Palermo, "Asymmetrie als Ordnungsmodell," 18-19.

$5^{\circ} \quad$ Gamper, "Gleichheit," 151-152.

$5^{1} \quad$ Watts, Systems, 127; Von Beyme, "Federalism," 433.

52 Pernthaler, "Asymmetrischer Föderalismus," 98. 
these cases, the allocations of powers normally feature two characteristics: on the one hand, some component units are vested with more powers than others which constitutes a quantitative difference. On the other hand, many regions enjoy specific powers that are particular to their own history and identity: this is the case, e.g., when the Scotland Act 1998 allocates Scots criminal and Scots private law to Scotland; when the Catalonian Statute or the Statute of TrentinoAlto Adige/South Tyrol establishes linguistic rights of the respective region or provinces, or the Belgian Constitution for the Belgian linguistic communities as 'personalised' component entities of the federal system, or when historical 'foral' law is recognised with regard to Navarra and the Basque country. ${ }^{53}$

Surely, not each and every competence that can be found in these special allocation systems is a perfect mirror of rationality and genuine distinctiveness. But quantitative and qualitative particularities are still clearly recognisable, and at least roughly pass the suum cuique-test. There still remains, however, a considerable margin of appreciation of how much and how far factual differences between component units should be recognised and implemented through differing allocation regimes. When allocation systems are static, constitutional amendments may, from time to time, be necessary in order to adapt them to new 'factual' symmetries or asymmetries. ${ }^{54}$ However, it is also remarkable that the particular situation in Italy's five special regions would have been maintained even by the failed constitutional reform draft of $2016 .{ }^{55}$ The Scotland Act 2016, by which further powers were devolved to Scotland, was a direct answer to the Scottish independence movement, and even if the Act could not anticipate new demands after the Brexit referendum, it nonetheless responded to Scotland's strong identity and the very particular history of its union with England.

\subsection{Asymmetries in Federal Second Chambers}

The second context examined here has traditionally been a focus of discussions on asymmetric federalism. In fact, it is as old as federalism itself, as old as the US Constitution of $1787 / 88$, and it was already intensely discussed in the Federalist Papers: it relates to the federal second chamber, namely the question of whether the component units should be represented equally or unequally

53 See also the examples given by Palermo, "Asymmetrie als Ordnungsmodell," 17.

54 Gamper, "Kompetenzverteilung," 778-780.

55 'Disposizioni per il superamento del bicameralismo paritario, la riduzione del numero dei parlamentari, il contenimento dei costi di funzionamento delle istituzioni, la soppressione del CNEL e la revisione del titolo v della parte II della Costituzione', Gazzetta Ufficiale Della Repubblica Italiana 157, no. 88 (April 2016), 1 et seq. 
(including weighted voting). ${ }^{56}$ According to the US Senate model, the states are represented equally, i.e. irrespective of their size, number of people, wealth or other factual indicators. Federalist No. 62 explains this solution to be 'the result of compromise between the opposite pretensions of the large and the small States', between the 'national' and the 'federal' principle, 'founded on a mixture of the principles of proportional and equal representation'. Considering that the first chamber consists of representatives elected on an asymmetric basis, the component states should be equally represented in the second chamber. The 'equal vote allowed to each State is at once a constitutional recognition of the portion of sovereignty remaining in the individual States, and an instrument for preserving that residuary sovereignty' ${ }^{\prime} 7$ On the other hand, it is argued in Federalist No. 22 that the 'right of equal suffrage among the States is another exceptionable part of the Confederation'; this is regarded as an 'impropriety of an equal vote between States of the most unequal dimensions and populousness' so that a minority (of the people) could rule over the majority (of the people), given that a majority of the states 'contain[s] less than a majority of the people..$^{58}$ What is found objectionable in the confederation, is thus accepted in the federation, but only because of the bicameral system which guarantees a balance between symmetric and asymmetric representation. Still, the discussion about symmetric or asymmetric representation confuses different issues: on the one hand, the external dimension, i.e. how the second chamber may interact vis-à-vis the first chamber, and, on the other hand, how the second chamber operates from its internal perspective.

Whether the component units still preserve a 'residuary sovereignty' in this first external dimension is less a matter of equal representation in the second chamber than a question of what powers the second chamber, as a whole, can exercise. If we imagine a weak second chamber whose decisions, even though based on equal representation, could be overturned by the first chamber, this will not be a striking token of a 'residuary sovereignty'. It is certainly true that the symmetric composition of the second chamber preserves the confederal idea ${ }^{59}$ of equal representation: the component units thus exercise equal

$5^{6}$ A similar dilemma arises where the component units directly participate in federal legislative processes in accordance with weighted voting or where regions are represented asymmetrically in unicameral parliaments (see, with examples, Palermo, "Asymmetrie als Ordnungsmodell," 17 fn. 17; Gamper, "Gleichheit," 154 fn. 53).

57 James Madison, "Federalist No. 62," The Federalist Papers, no. 62 (1788).

58 Alexander Hamilton, "Federalist No. 22," The Federalist Papers, no. 22 (1787).

59 Hans Kelsen, Allgemeine Staatslehre (Berlin: Julius Springer, 1925), 217. On the equality of sovereign states under international law as an inspiration for coming-together federations 
suffrage within the internal decision-making process. However, this does not say anything about whether these decisions will have any particular weight in the parliamentary process as a whole and whether these are a token of a 'residuary sovereignty'.

Secondly, equal representation does not guarantee each component unit a right to enforce its own will upon the others. ${ }^{60}$ It would be paradoxical indeed to assume such a right for each and every component unit which would, of course, entail conflicting and irresolvable situations. Even where the unanimity principle prevailed - which is not usual for federal second chambers worldwide - one component unit cannot, not even by boycotting the decision made by others, enforce its own preferred decision. Normally, however, decision-making in federal second chambers relies on simple or qualified majorities. Equal representation would, therefore, not protect individual units from being overruled by the representatives of other units. The only difference is that, under symmetric representation, a majority of the votes cast would always demand a majority of the component units themselves (provided that their representatives were present), whereas, under asymmetric representation, a majority of the votes cast could possibly be reached by a minority of component units (through their representatives). As a corollary, symmetric representation cannot protect individual units (their representatives) from being overruled by the others, as long as decisions are made by whatever kind of majority instead of unanimity. Asymmetric representation, therefore, does not particularly threaten individual component units, but rather constitutes a challenge between competing majorities - majorities of the component units and majorities of their representatives. Accordingly, decisions may turn out to be counter-majoritarian and hegemonic ${ }^{61}$ when perceived from either perspective.

Turning to the possible indicators underlying asymmetric representation, we do not only find that a majority of federal constitutions have decided against the US Senate model, ${ }^{62}$ but also that they mostly use the number of people - rather than mere territorial size or economic criteria - as a base value. ${ }^{63}$ There are exceptions, though, such as the six Swiss half-cantons that

that emerge from confederations, see also Hans Huber, "Die Gleichheit der Gliedstaaten im Bundesstaat," Zeitschrift für öffentliches Recht, no. 18 (1968): 247.

6o Gamper, "Gleichheit," 164.

61 Kelsen, Staatslehre, 219.

62 See Gamper, "Gleichheit," $155^{-156}$. Absolutely equal representation is a requisite for the composition of the second chambers of Russia, South Africa and Indonesia.

63 Kelsen, Staatslehre, 217-218; Watts, Systems, 152; Gamper, "Gleichheit," 155-156. 
are represented in the federal second chamber with just one representative each; this is not due to their population size, when compared to the other cantons, but to their history as 'separated' cantons. ${ }^{64}$ In those cases, where representation is adjusted in accordance with demographic asymmetries, many federal constitutions only provide fixed numbers, irrespective of demographic changes, while others, more dynamically, require adaptations according to the national census; alternatively, they use an arithmetic system as a basis, but allow for geometric deviations of the number of representatives. ${ }^{65}$ Moreover, federal constitutions vary as to whether they consider the number of regional inhabitants, of regional citizens, or of regional citizens with the right to vote (regarding the first chamber); they often deviate from their own systems through means of over- or under-proportional representation, by prescribing minimum and/or maximum numbers of delegates or generalise proportions in accordance with fixed classes. ${ }^{66}$ Over- or under-proportional representation is used to counterbalance extreme factual asymmetries which has a slightly 'confederalising' effect: regions with a very low number of people that would, under a strictly proportional model, hardly be represented at all are thus guaranteed some minimum representation, whereas a maximum number ensures that regions with the largest number of people are not represented by a comparatively exorbitant number of representatives; this 'positive discrimination' measure may be used to favour smaller units. ${ }^{67}$ In several cases, further asymmetries are constituted by the inclusion of members appointed for other reasons than federalism, ${ }^{68}$ by the different treatment of different categories of component units ${ }^{69}$ or by specific minority protection-oriented representation targeted at positive discrimination ${ }^{70}$ sometimes certain representatives are selected for combined purposes. ${ }^{71} \mathrm{~A}$ two-fold asymmetry could be created in cases with an asymmetric allocation of powers if representatives of component units with stronger powers were not allowed to vote in certain legislative procedures at the federal level: accordingly, where federal laws are to be enacted only for some component units, in areas not falling within their power,

64 Giovanni Biaggini, “Asymmetrien im schweizerischen Bundesstaat?," in Auf dem Weg zu asymmetrischem Föderalismus?, eds. Francesco Palermo et al. (Bozen: Nomos, 2007), $5^{8}$.

65 Gamper, "Gleichheit," 156.

66 See, with examples, Watts, Systems, 147-153; Gamper, "Gleichheit," 155-158.

67 Watts, Systems, 152-153; Palermo, "Asymmetrie als Ordnungsmodell," 17.

68 See, most recently, Art. 86 para 2 subpara b of the Constitution of Nepal.

69 See e.g. Sec 22 of the Canadian Constitution Act 1867.

70 See, most recently, Art. 86 para 2 subpara a of the Constitution of Nepal.

71 The most recent example is Art. 86 para 2 subpara a of the Constitution of Nepal. See also Palermo, "Asymmetrie als Ordnungsmodell," 17. 
whereas stronger component units can enact their own laws in the same field autonomously, the representatives of the latter would abstain from voting. ${ }^{72}$

Although the Federalist's political explanation of the 'compromise' is perfectly plausible in the context of US American federalism, its implications may be overestimated in other contexts. The fact that most federal systems provide for imperfect rather than perfect bicameralism further lessens the significance of the second chamber and its composition. Moreover, asymmetric representation may be smoothed out if majorities need to be built on specific approval by the component units (their delegations) rather than the simple majority of votes cast. Art. 35 para 4 of the Austrian Federal Constitutional Act $^{73}$ offers an interesting example here: certain constitutional amendments not only require a majority of the votes cast in the Federal Council, but require a further majority, namely a majority of the representatives of at least four (out of nine) Länder. As a consequence, these amendments would not pass unless approved by a 'double majority'. Even if a minority of the Länder (due to their large number of people and thus representatives in the Federal Council) command a sufficient majority of the votes cast, they still would not be successful if the majority of representatives of at least six Länder voted against. The second 'majority' does not, of course, refer to a majority of Länder (four are sufficient), but refers to having a majority in each Land's delegation. However, the provision ensures that a small minority of up to three Länder (through their representatives in the Federal Council) will not be able to enforce such a decision, even though they represent a majority of the people and, accordingly, representatives in the Federal Council. This example shows that it depends on the type of majority whether asymmetric representation truly privileges component units with larger numbers of people. ${ }^{74}$

When federal constitutions provide for the asymmetric composition of second chambers, the rationale mainly lies with democratic purposes. ${ }^{75}$ Whereas

72 Similarly - with regard to the lack of an English Parliament and to 'only England' laws enacted by the Westminster Parliament - the 'West Lothian Question' has been discussed, although not resolved in the United Kingdom; see Watts, Systems, 130; Leyland, "Dynamics," 265-267.

73 See Gamper, "Gleichheit," 158; Anna Gamper, "Artikel 35 B-vG," in Österreichisches Bundesverfassungsrecht, eds. Karl Korinek et al. (Vienna: Verlag Österreich, 2017), marginal nos. 49-52.

74 Another interesting example is Art. IV $\S 3$ subparas d-f of the Constitution of Bosnia and Herzegovina, according to which special double majorities of territorial representatives are needed; or special laws in accordance with Art. 4 para 3 of the Belgian Constitution which require special majorities of the representatives of the linguistic groups.

Watts, Systems, 154-155. 
most systems of asymmetric representation are roughly guided by the numerical proportions between the 'component peoples', this is also an attempt to guarantee equal representation of all federal citizens. In fact, there is some structural similarity to the distribution of mandates between electoral districts in first-chamber elections. ${ }^{76}$ Must we conclude, therefore, that equal representation in federal second chambers, as in the US Senate, is undemocratic? The authors of the Federalist Papers deliver an ambivalent assessment. They do indeed condemn equal representation in the confederal context, while accepting it for the federal Senate. Their first argument is rather less concerned with equality theory but reason of state, when they frankly admit: 'A government founded on principles more consonant to the wishes of the larger States, is not likely to be obtained from the smaller States [... The] advice of prudence must be to embrace the lesser evil. ${ }^{77}$ But, secondly, they argue that equal representation preserves the residuary sovereignty of the states. ${ }^{78}$ To stretch this argument further: does it constitute a reasonable justification to compensate states for the loss of their sovereignty by granting them equal representation in the Senate? Or, rather, does their equal representation mirror the tiny rest of their former sovereignty exactly as the suum cuique-test would demand? When states lose their sovereignty because they agree on a federal system, but nevertheless retain some part of it, ${ }^{79}$ is their equal representation just a proper and reasonable claim emanating from 'residuary sovereignty'? If the answer is yes, the justification, made from a comparison between different historical perspectives, will be diachronic. In constitutional reality, however, justification for asymmetric representation is mainly synchronic inasmuch as certain circumstances of the present are considered by the federal constitution. If we regard the suum as something dynamic, that needs to adapt itself according to circumstances, it will fall into the second category; if the suum, however, is contextualised with the past, equal representation might turn out to be the adequate compensation for states that lost their full sovereignty. Similarly, the Swiss half-cantons enjoy only half-representation, since they were not originally units in their own right. Still, the diachronic argument is valid only for original or coming-together federations, and the Federalist Papers knew only those. Holding-together federations that lack a constitutional compact

\footnotetext{
76 Gamper, "Gleichheit," 155 .

77 Madison, "Federalist No. 62."

78 Madison, "Federalist No. 62."

79 Frank Delmartino, "New Dimensions of Asymmetry in (Quasi-) Federal States and in the European Union," in Asymmetries in Constitutional Law, eds. Francesco Palermo, Carolin Zwilling and Karl Kössler (Bozen: EURAC, 2009), 37.
} 
between formerly independent units cannot argue that they need to protect the 'residuary sovereignty' of their regions.

As Ronald L. Watts ${ }^{80}$ rightly argued, federalism enriches the democratic landscape - when regional institutions are elected or when instruments of regional direct democracy are exercised. This is, however, not a particular feature of federal systems with equal representation in the federal second chamber, but common to all federal systems. Still, the argument can be deployed also for equal representation cases: even though deficits in federal democracy cannot be 'compensated' by component democracy, the latter nevertheless improves the democratic nature of the overall system.

\subsection{Asymmetries in Fiscal Equalisation}

Fiscal equalisation is perhaps the most striking element found in most federal systems in which the equality dilemma between the component units is revisited. ${ }^{81}$ Despite the great variety and complexity of equalisation mechanisms, their common idea is to distribute financial resources or revenues between and among the different tiers in order to allow them to perform their tasks. ${ }^{82}$ Particular attention is drawn to factual differences between tiers or different units belonging to the same tier, also with a view to balance these differences and adapt the financial situation to factual needs. One way to do this is by allotting financial revenues from one level to the other or, at the same level, from one or more units at that level to the other(s). If this is done in a vertical way, it is mostly the federal government that allots financial revenues that derive from the federal tax yield to the component units. ${ }^{83}$ Horizontal equalisation, in contrast, requires a transfer of financial revenues between units of the same level, i.e. between regions or, respectively, between local governments. ${ }^{84}$ In a wider sense, fiscal equalisation entails transfers on a more specific and irregular basis; they refer to particular situations of need or respond to tasks that are particularly challenging so that specific resources are required. Whether the number of inhabitants is taken as a proportional key or whether it is used for over- or under-proportional classification or whether other keys are used, varies from system to system.

\footnotetext{
$80 \quad$ Watts, Systems, 155 .

81 Watts, Systems, 129-130; Kincaid, "Observations," 426.

82 Watts, Systems, 103-112 and 130; Watts, "Conclusions," 334-335.

83 Watts, Systems, 103. See also Anwar Shah, "Comparative Conclusions on Fiscal Federalism," in A Global Dialogue on Federalism, Vol. 4: The Practice of Fiscal Federalism: Comparative Perspectives, ed. Anwar Shah (Montreal: McGill-Queen's University Press, 2007), 387. 
Fiscal equalisation is incompatible with formal equality, since it is targeted at compensating and balancing inequalities between and among tiers. It is thus necessary not to treat all component units equally, but distinctly - not in an arbitrary way, of course, but according to actual needs due to number of inhabitants, structural problems, minority protection, emergencies or other particularities that require financing, as well as according to the tasks to be performed by each level. As $\S 4$ of the Austrian Fiscal Constitutional Act, which is said to enshrine a particular fiscal equality principle, ${ }^{85}$ states: fiscal equalisation 'has to be in line with the distribution of encumbrances stemming from public administration and has to take into consideration that the capacity of the concerned territorial entities is not exceeded.' The criteria are thus twofold: on the one hand, fiscal equalisation has to consider the tasks that are to be performed by the territorial entities, which refers to the allocation of powers; on the other hand, it is also their individual capacity and efficiency which itself derives from certain conditions. ${ }^{86}$

It would thus appear that the suum cuique-test serves as the very basis for fiscal equalisation. There are, however, a number of objections to be made: firstly, no system of fiscal equalisation can avoid generalisation or a certain rigidity of figures and quotas. Moreover, fiscal equalisation at least partly relies on fixed parameters whether valid for a couple of years or even longer; structural adaptations of fiscal equalisation systems usually depend on complex procedures that often require intergovernmental commissions, negotiations and compromises. ${ }^{87} \mathrm{~A}$ particular problem is, moreover, posed regarding horizontal equalisation, as this requires financial solidarity between regions. ${ }^{88}$ Accordingly, richer regions are asked to share financial resources with poorer regions which may increase tensions between them. Secessionist tendencies are not infrequently triggered by economic and financial discrepancies between regions and their different approaches towards financial solidarity. ${ }^{89}$ Even the wellknown Länderfinanzausgleich in Germany has now been replaced by a system

85 See, with more detail, Hans Georg Ruppe, "§ 4 F-vG," in Österreichisches Bundesverfassungsrecht, eds. Karl Korinek et al. (Vienna: Verlag Österreich, 2016).

86 See also Pernthaler, "Asymmetrischer Föderalismus," 110; Bußjäger, "Bundesstaat," 295-296.

87 Watts, Systems, 112-116.

88 See, with more detail, Shah, "Conclusions," 389-39o.

89 Charles D. Tarlton's controversial formula that ' $[w]$ hen diversity predominates, the 'secession-potential' of the system is high' (Tarlton, "Symmetry," 873) is acceptable inasmuch as he speaks of a 'potential' and not of an inevitability; see also Burgess, "Paradox," 34. The question, however, is if de facto or de iure asymmetries are meant: while de facto asymmetries may increase the potential, de iure asymmetries normally intend the opposite, namely to satisfy needs for more or different kinds of autonomy. 
according to which the federal level, instead of the richer Länder, is mainly responsible for subsidising the poorer Länder. ${ }^{90}$ On the whole, fiscal equalisation realises the Aristotelian concept of redistributive justice inasmuch as poorer regions are given 'their own' not in accordance with their capacity, but in accordance with their tasks and needs ${ }^{91}$ - in a way, this is a positive discrimination measure.

But is it in line with the suum cuique-test to request adequate resources for poorer regions while at the same time requiring richer regions to pay? Does it correspond to factual differences to pay or to receive respectively, or could richer regions, for instance, claim to keep their 'own' money or to demand structural reforms for poorer regions in order to improve their financial situation? Neither approach, as such, would seem to be irrational or disproportionate. This is probably one of the reasons why solidarity rules or strong equalisation measures are often entrenched in federal constitutional law; as a consequence, the respective provisions will not be subject to judicial review or examined against the yardstick of the equality principle.

\section{4}

\section{Conclusions}

When we regard the suum cuique-test from the viewpoint of its judicial enforcement and justiciability, a significant difference between individual and collective equality appears. Individuals can normally complain against violations of their equality rights before courts, including, where provided, a specialised constitutional court. These violations arise from unconstitutional laws or other unconstitutional legal acts that are accordingly repealed, not applied or declared to be void. Conversely, asymmetries in federal systems are often non-justiciable, since they are rooted in federal constitutional law. When, for instance, a federal constitution provides for asymmetric representation in the federal second chamber, these provisions form constitutional leges speciales that cannot be measured against the yardstick of the equality principle, which is entrenched in the same federal constitution. The same is true for federal constitutional norms that provide for different classes of subnational units, for asymmetric allocations of powers or fiscal equalisation. From this perspective,

9o See, in particular, the new Art. 107 para 2 of the German Basic Law; Anna Gamper, "Tausch und Reform: Die Änderung des Grundgesetzes 2017," in Jahrbuch für Föderalismus 2017, ed. Europäisches Zentrum für Föderalismus-Forschung Tübingen (Baden-Baden: Nomos, 2017).

Similarly, Fleiner and Gaudreault-DesBiens, "Federalism," 152. 
the question of whether the respective asymmetry passes the suum cuique-test is, indeed, irrelevant. ${ }^{92}$

As a consequence, the asymmetric treatment of federal citizens, which emanates from differing laws on account of an asymmetric allocation of powers, is not justiciable either; a possible claim to submit the resulting inequalities under equality review will fail. The justiciability of individual equality cases entails - at least under strong-form judicial review ${ }^{-93}$ that independent courts will have the ultimate say on the suum cuique. It is up to them to assess the criteria of proportionality and reasonableness. As long as the constitution-maker does not critically respond by amending the constitution, these decisions will be final. In contrast, the aforementioned inequalities in federal systems will not routinely be for the judiciary to decide. The federal constitution-maker establishes them, and this is, first and foremost, a political decision.

As this chapter has sought to point out, however, asymmetries in federalism are hardly ever born from unreasonable and arbitrary political decisions, even if this were possible (on a federal constitutional basis). Empirically, constitutional asymmetries normally are grounded on a rationale such as the specific historical, ethnic or cultural identity, geographical indicators or economic and financial resources. ${ }^{94}$ Admittedly, not all constitutional asymmetries are perfectly compatible with the suum cuique-test, since they usually cannot avoid generalisation, rigidity, as well as a certain proneness to political compromise. But their strongest motivation still is a legal reflection of individual positions so that de iure asymmetry at least roughly mirrors de facto asymmetry. While it would be wrong to hold only formal equality as 'true' equality, it would be wrong as well to hold only symmetric federal states as strongholds of 'true' federalism; it would be strange indeed that a principle which stands for diversity in unity should cherish unconditional symmetry. ${ }^{95}$ Even the Federalist Papers bluntly describe the rationale behind equal representation of the component units as a political deal between the larger and smaller states rather than as a theoretical essential of federalism - and why should symmetry be an essential, where federalism does not even emerge from an agreement between independent states? ${ }^{96}$

92 Gamper, "Gleichheit," 166.

93 See, paradigmatically, Mark Tushnet, Weak Courts, Strong Rights: Judicial Review and Social Welfare Rights in Comparative Constitutional Law (Princeton: Princeton University Press, 2008).

94 Pernthaler, "Asymmetrischer Föderalismus," 106; Palermo, "Asymmetrie als Ordnungsmodell," 13-14; Gamper, "Kompetenzverteilung," 767.

95 Similarly, Palermo, "Asymmetries in Constitutional Law," 11.

96 Madison, "Federalist No. 62." 
However, not every type of asymmetry between territorial units can qualify them as components of a federal (and not any decentralised) system, and this demands what Peter Pernthaler called 'bündische Gleichheit' ${ }^{97}$ between the federal and the component levels. ${ }^{98}$ If asymmetric federalism allowed for everything or anything on an open scale between centralisation and decentralisation, every asymmetrically decentralised state in the world could claim to be a federal state. ${ }^{99}$

Suum cuiqe tribuere is a Janus-faced principle, as are equality and federalism. So far, it serves as a common narrative to both. Neither is there just one suum, nor is there just one equality, ${ }^{100}$ or one federalism. ${ }^{101}$ However, federalism is more than just an attribution of any suum to a number of tiers and units. ${ }^{102}$ It is based on the conditions of self-rule and shared-rule that, where necessary, would allow overruling even individual equality. The suum is embedded in, and not beyond these conditions.

\section{Bibliography}

Agranoff, Robert, ed. Accommodating Diversity: Asymmetry in Federal States. BadenBaden: Nomos, 1999.

Aristotle. Ethika Nikomacheia.

Aristotle. Politika.

Baer, Susanne. "Equality." In The Oxford Handbook of Constitutional Law, edited by Michel Rosenfeld and András Sajo, 982-1001. Oxford: Oxford University Press, 2012. Basta Fleiner, Lidija R. and Jean-François Gaudreault-DeBiens. "Federalism and Autonomy." In Routledge Handbook of Constitutional Law, edited by Mark Tushnet, Thomas Fleiner and Cheryl Saunders, 143-158. London, New York: Routledge, 2013. Biaggini, Giovanni. "Asymmetrien im schweizerischen Bundesstaat?" In Auf dem Weg zu asymmetrischem Föderalismus?, edited by Francesco Palermo, Rudolf Hrbek, Carolin Zwilling and Elisabeth Alber, 54-64. Bozen: Nomos, 2007.

97 Pernthaler, "Differenzierter Föderalismus," 24.

98 Gamper, "Gleichheit," 147.

99 Francesco Palermo and Karl Kössler rightly observe that, despite differing criteria and incomplete definitions of federalism, these are 'nevertheless fundamental to approach a full understanding of a complex phenomenon' such as federalism; Francesco Palermo and Karl Kössler, Comparative Federalism, Constitutional Arrangements and Case Law (Portland: Hart, 2017), 65.

100 Gamper, "Gleichheit," 146.

101 Palermo, "Asymmetries in Constitutional Law," 13.

102 Gamper, "Gleichheit," 166. 
Bryde, Brun-Otto and Michael A. Stein. "General Provisions Dealing with Equality." In Routledge Handbook of Constitutional Law, edited by Mark Tushnet, Thomas Fleiner and Cheryl Saunders, 287-30o. London, New York: Routledge, 2013.

Burgess, Michael. "The Paradox of Diversity - Asymmetrical Federalism in Comparative Perspective." In Asymmetries in Constitutional Law, edited by Francesco Palermo, Carolin Zwilling and Karl Kössler, 21-35. Bozen: EURAC, 2009.

Burgess, Michael. Comparative Federalism: Theory and Practice. London: Routledge, 2006.

Bußjäger, Peter. "Bundesstaat und Gleichheitsgrundsatz." Juristische Blätter 129, no. 5 (2007): 289-298.

Bußjäger, Peter. “Die bundesstaatliche Kompetenzverteilung in Österreich.” In Föderale Kompetenzverteilung in Europa, edited by Anna Gamper, Peter Bußjäger, Ferdinand Karlhofer, Günter Pallaver and Walter Obwexer, 523-574. Baden-Baden: Nomos, 2016.

Bußjäger, Peter. Föderale Systeme. Vienna: Jan Sramek, 2016.

Bußjäger, Peter. Homogenität und Differenz. Vienna: Braumüller, 2006.

Delmartino, Frank. "New Dimensions of Asymmetry in (Quasi-) Federal States and in the European Union." In Asymmetries in Constitutional Law, edited by Francesco Palermo, Carolin Zwilling and Karl Kössler, 37-45. Bozen: Eu RAC, 2009.

Gamper, Anna. “'Arithmetische' und 'geometrische' Gleichheit im Bundesstaat.” In Vom Verfassungsstaat am Scheideweg - FS Peter Pernthaler, edited by Karl Weber and Norbert Wimmer, 143-166. Vienna, New York: Springer, 2005.

Gamper, Anna. “Artikel 35 B-VG.” In Österreichisches Bundesverfassungsrecht, edited by Karl Korinek, Michael Holoubek, Christoph Bezemek, Claudia Fuchs, Andrea Martin and Ulrich E. Zellenberg, 1-41. Vienna: Verlag Österreich, 2017.

Gamper, Anna. "Föderale Kompetenzverteilung in Europa: Vergleich und Analyse aus verfassungsrechtlicher Sicht.” In Föderale Kompetenzverteilung in Europa, edited by Anna Gamper, Peter Bußjäger, Ferdinand Karlhofer, Günter Pallaver and Walter Obwexer, 763-784. Baden-Baden: Nomos, 2016.

Gamper, Anna. "Tausch und Reform: Die Änderung des Grundgesetzes 2017." In Jahrbuch für Föderalismus 2017, edited by Europäisches Zentrum für FöderalismusForschung Tübingen, 114-125. Baden-Baden: Nomos, 2017.

Gamper, Anna. Staat und Verfassung. Vienna: Facultas, 2014.

Hamilton, Alexander. "Federalist No. 22." The Federalist Papers, no. 22 (1787).

Huber, Hans. "Die Gleichheit der Gliedstaaten im Bundesstaat." Zeitschrift für öffentliches Recht, 18 (1968): 247-261.

Keating, Michael. "Asymmetrical Government: Multinational States in an Integrating Europe." Publius 29, no. 1 (1999): 71-86.

Kelsen, Hans. Allgemeine Staatslehre. Berlin: Julius Springer, 1925.

Kelsen, Hans. Die Illusion der Gerechtigkeit. Vienna: Manz Verlag, 1985.

Kelsen, Hans. Reine Rechtslehre. Vienna: Verlag Österreich, 2000. 
Kelsen, Hans. Was ist Gerechtigkeit? Vienna: Deuticke, 1953.

Kincaid, John. "Comparative Observations." In A Global Dialogue on Federalism, Vol. 1:

Constitutional Origins, Structure, and Change in Federal Countries, edited by John Kincaid and Alan Tarr, 409-448. Montreal: McGill-Queen's University Press, 2005. Leyland, Peter. "The Multifaceted Constitutional Dynamics of U.K. Devolution." International Journal of Constitutional Law 9, no. 1 (2011): 251-273.

Madison, James. "Federalist No. 62." The Federalist Papers, no. 62 (1788).

Palermo, Francesco and Karl Kössler. Comparative Federalism, Constitutional Arrangements and Case Law. Portland: Hart, 2017.

Palermo, Francesco, Carolin Zwilling and Karl Kössler, eds. Asymmetries in Constitutional Law. Bozen: EURAC, 2009.

Palermo, Francesco, Rudolf Hrbek, Carolin Zwilling and Elisabeth Alber, eds. Auf dem Weg zu asymmetrischem Föderalismus?. Bozen: Nomos, 2007.

Palermo, Francesco. "Asymmetrie als Ordnungsmodell des modernen Föderalismus. Eine vergleichende Analyse." In Auf dem Weg zu asymmetrischem Föderalismus?, edited by Francesco Palermo, Rudolf Hrbek, Carolin Zwilling and Elisabeth Alber, 9-21. Bozen: Nomos, 2007.

Palermo, Francesco. "Asymmetries in Constitutional Law - An Introduction." In Asymmetries in Constitutional Law, edited by Francesco Palermo, Carolin Zwilling and Karl Kössler, 11-17. Bozen: EURAC, 2009.

Pernthaler, Peter. "Asymmetrischer Föderalismus als systemübergreifender Ordnungsrahmen der Regionalautonomie." In Die Verfassung der Südtiroler Autonomie, edited by Joseph Marko, Sergio Ortino, Francesco Palermo, Leonhard Voltmer and Jens Woelk, 97-114. Bozen: Nomos, 2005.

Pernthaler, Peter. "Differenzierter Föderalismus.” In Auf dem Weg zu asymmetrischem Föderalismus?, edited by Francesco Palermo, Rudolf Hrbek, Carolin Zwilling and Elisabeth Alber, 22-28. Bozen: Nomos, 2007.

Pernthaler, Peter. Der differenzierte Bundesstaat. Vienna: Braumüller, 1992.

Plato. Gorgias.

Plato. Nomoi.

Plato. Politeia.

Poggeschi, Giovanni. "Federalism in Russia: Ethnic and Asymmetrical." In Asymmetries in Constitutional Law, edited by Francesco Palermo, Carolin Zwilling and Karl Kössler, 97-116. Bozen: EURAC, 2009.

Ruppe, Hans Georg. “§ 4 F-VG.” In Österreichisches Bundesverfassungsrecht, edited by Karl Korinek, Michael Holoubek, Christoph Bezemek, Claudia Fuchs, Andrea Martin and Ulrich E. Zellenberg, 1-6. Vienna: Verlag Österreich, 2016.

Shah, Anwar. "Comparative Conclusions on Fiscal Federalism." In A Global Dialogue on Federalism, Vol. 4: The Practice of Fiscal Federalism: Comparative Perspectives, edited by Anwar Shah, 370-393. Montreal: McGill-Queen's University Press, 2007. 
Swenden, Wilfried. "Asymmetric Federalism and Coalition-Making in Belgium." Publius 32, no. 3 (2002): 67-87.

Tarlton, Charles D. "Symmetry and Asymmetry as Elements of Federalism: A Theoretical Speculation." The Journal of Politics 27, no. 4 (1965): 861-874.

Tillin, Louise. "United Diversity? Asymmetry in Indian Federalism." Publius 37, no. 1 (2006): 45-67.

Tushnet, Mark. Weak Courts, Strong Rights: Judicial Review and Social Welfare Rights in Comparative Constitutional Law. Princeton: Princeton University Press, 2008.

Von Beyme, Klaus. "Asymmetric Federalism between Globalization and Regionalization." Journal of European Public Policy 12, no. 3 (2005): 432-447.

Waldstein, Wolfgang. "Ist das 'Suum cuique' eine Leerformel?" In Ius Humanitatis - FS Alfred Verdross, edited by Herbert Miehsler, Erhard Mock, Bruno Simma and Ilmar Tammelo, 285-320. Berlin: Dunker \& Humblot, 198 o.

Waldstein, Wolfgang. "Zu Ulpians Definition der Gerechtigkeit." In FS Werner Flume, edited by Horst H. Jakobs, Brigitte Knobbe-Keuk, Eduard Picker and Jan Wilhelm, 213-232. Köln: Verlag Dr. Otto Schmidt KG, 1978.

Watts, Ronald L. "Comparative Conclusions." In A Global Dialogue on Federalism, Vol. 2: Distribution of Powers and Responsibilities in Federal Countries, edited by Akhtar Majeed, Ronald L. Watts and Douglas M. Brown, 322-349. Montreal: McGill-Queen's University Press, 2006.

Watts, Ronald L. "Federalism, Federal Political Systems, and Federations." Annual Review of Political Science 1 (1998): 117-137.

Watts, Ronald L. Comparing Federal Systems. Montreal, Kingston: McGill-Queen's University Press, 2008. 